FACTA UNIVERSITATIS

Series: Architecture and Civil Engineering Vol. 11, N ${ }^{\mathrm{o}}$ 1, 2013, pp. 97 - 105

DOI: 10.2298/FUACE1301097D

\title{
USING DAPHNIA BIO-SENSOR FOR RANDOM NUMBER GENERATION *
}

UDC 504.4:595.324:004=111

\author{
Đorđe Đorđević ${ }^{1}$, Srbislav Nešić ${ }^{2}$ \\ ${ }^{1}$ University of Niš, Faculty of Civil Engineering and Architecture, Serbia \\ ${ }^{2}$ Construction Cluster "Dundjer," Niš, Serbia \\ djoka@ni.ac.rs
}

\begin{abstract}
One of the most used bioassays for toxicity screening of chemicals and for toxicity monitoring of effluents and contaminated waters is the acute toxicity test performed with Daphnia Magna. Standard methods have been developed and gradually improved by national and international organizations dealing with toxicity testing procedure, in view of its application within a regulatory framework. As for all toxicity tests, the organisms used for the acute Daphnia magna assay have to be obtained from live stocks which are cultured in the laboratory on live food (micro-algae). The technical and biological problems inherent in year-round culturing and the culturing/maintenance costs of live stocks restricts its application to a limited number of highly specialized laboratories. This bottleneck in toxicity testing triggered investigations forward the concept of "microbiotests" or "small-scale" toxicity tests.

This paper deals with the measurement of changes in the behavior of Daphniae using device BIOTOXINOMER, awarded by Ministry for Science and Technological Development of Republic Serbia with Diploma for best Innovation idea in year 2010 in category Medicine, Health, and Ecology. Actually, the main topic is digitalization of bio-monitoring results and random number generating on the base of Daphniae movement (distance). The on-line monitoring is available on site www.dundjer.co.rs/Daphniae and open-source software support is available on the same site.
\end{abstract}

Key words: Bio-sensoring, Water quality, Random number generator.

\footnotetext{
Received June 18, 2013

${ }^{*}$ Acknowledgement: The device described here has been awarded from Ministry of Science and Technology of Republic Serbia by Diploma for the Best Innovation Idea in the field of Medicine, Health, and Environment in the year 2010. (Fig. 13) . This work is in part supported by the Serbian Ministry of Education and Science (research projects III44006 and TR37003).
} 


\section{BASIC Working PRINCIPLE OF DEVICE}

BIOTOKSINOMER is the device for water quality control using small water crustacean - (shrimp) Daphnia, named water flea (Fig. 1.), which is very sensitive to the presence of toxins in the water and therefore informs and warns in real time on presence of toxins in water.

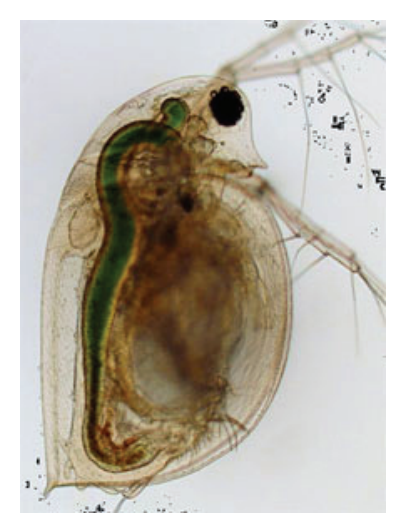

The innovation of the device is in the function of real time identification and early warning system for bad quality of drinking water, what is realized by implementation of device on the entrance of raw water into water purification plant or entry of waste water into the river, or using bypass for taking river water for Daphnia test. In that way this unique device provides on-line 24-hour monitoring of water quality or identification the presence of dangerous substances in water. The device achieves it in a quick, inexpensive and ecologically acceptable way. If Daphnia can survive in test water, then the water is safe for humans and water animals. If Daphnia dies (or only reduce movement), it means that water is in some way contaminated. This water test is quality water

Fig. 1 Daphnia test which should be followed by quantity test (chemical analysis) after any indications of contamination, i.e. presence of toxins.

"Biotoksinomer" works through a simple and cheap hardware and complex and sophisticated software. The real core of the device is an unique software that has the ability to perceive the death of Daphniae in real time (by counting them) or indicate slower activity (movement) of Daphniae and immediately informs the competent.

The device consists of bioassay with 2 chambers, one with a control group Daphnia, which is located in stable water conditions (conditions that are imitating Daphnias natural environment) and the second chamber through which flows constantly raw water, with desired dynamics, before treatment into the drinking water, that contains Daphnia testing group (Fig. 2).

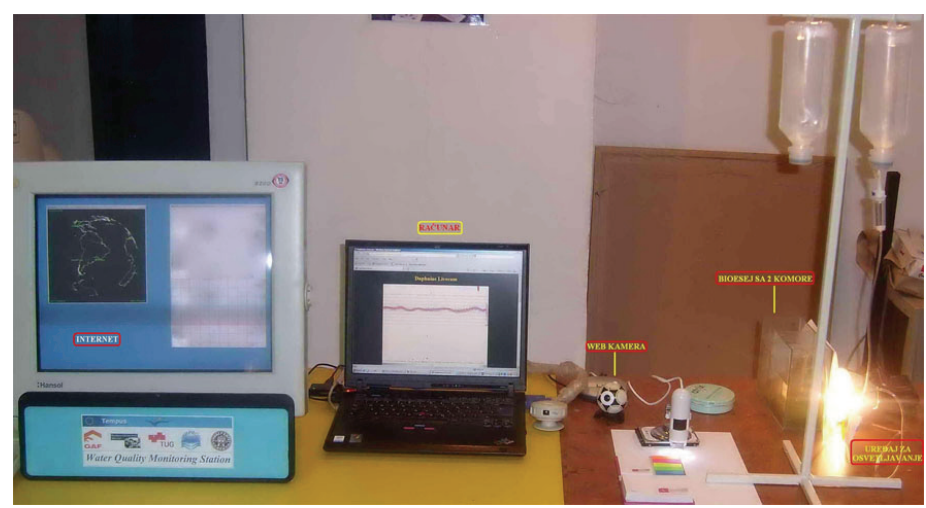

Fig. 2 Biotoksinomer 
Using simple web camera (Fig. 3) and own designed software, this system is at least 10 times cheaper than similar devices (using infra-red rays camera). This camera in a short period of time (every 300-500 msec. or even $1 \mathrm{sec}$.), round a clock ( 24 hours a day) shoots and records Daphnia position, number, size, and movement in chambers. Actually, software performs the analysis of successive photographs captured by webcam, and monitors the number, size and mobility of Daphnia. When the numbers of live Daphnia in the test chamber falls below $50 \%$ or more (limit determined by European Daphnia test of toxicity, EC50), the alarm is activated (Fig. 4) in order to inform that raw water is not correct for the standard treatment into the drinking water (because of the presence of toxic substances), or that waste water is polluted, or that river water is dangerous for river life, i.e. river ecosystem.

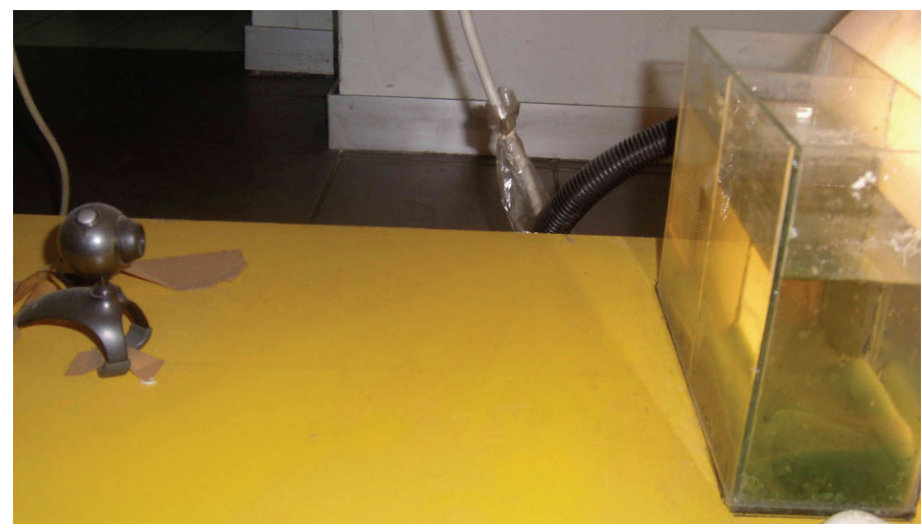

Fig. $3 \mathrm{Web}$ camera and aquarium

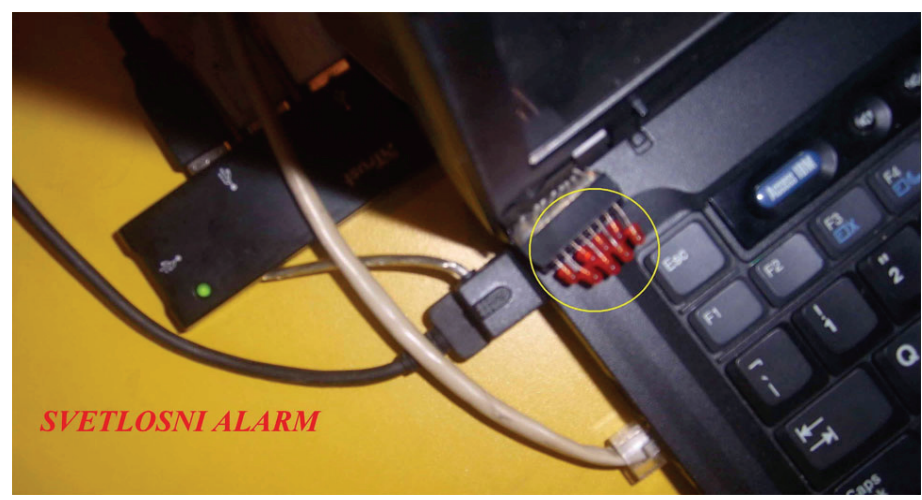

Fig. 4 Light alarm

The data is automatically sent to the server, and by SMS or the Internet to the authorities that are in charge to switch off the flow of water. Then it is necessary immediately to switch off the supply of raw water to treatment plant because the water contains some toxin(s) that caused the death (or immobility) of Daphnia. The software automatically sends data to the server and graphically displays the state of Daphnia in the last 24 hours (Fig. 5), and throughout the year, what can be monitored online via Internet. 
The program could be given the thresholds so that when the number of "fleas" is not into the given interval, the alarm is activated. Quiet alarm is red light on the desk. Sound alarm is emitted by small PC loud speakers. In addition, there is a Skype alarm where PC send the messages to enlisted users and e-mail alarm with sending e-mails to pre-defined addresses. With installed GSM Gateway program, PC could send additional SMS alarm or necessary information. The data collected from all measure stations are stored on server and presented on its WEB page. There is also a possibility to send current (real-time) and

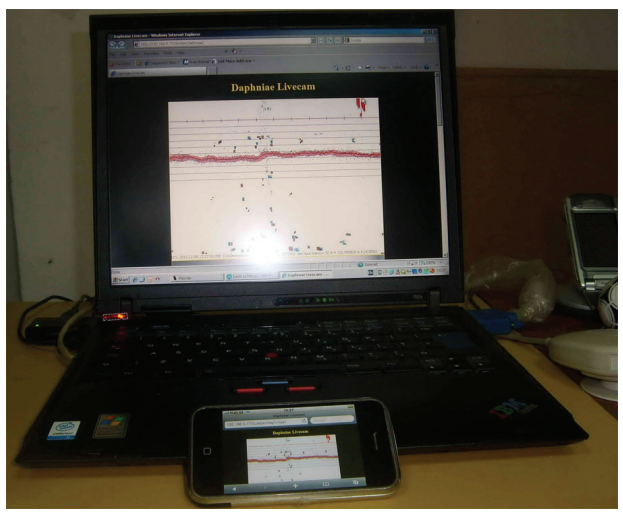

Fig. 5 State of Daphniae in bioassay round a clock periodical reports to distinct addresses in a different way (e-mail, Skype, SMS).

In addition to WEB report, using developed software - client application, it is possible to reach all the data from any measure point and get miscellaneous reports, control the measure stations on distance, or simple get measure data for own analysis.

\section{DATA TRACKING AND RECORDING}

Web camera is shutting the aquarium round o clock, in distinct period of time (300 $\mathrm{ms}, 600 \mathrm{~ms}$, or $1 \mathrm{sec}$ ), depending on camera and Daphnia state. After first shutting, we have gray scale picture given in Fig. 6 .

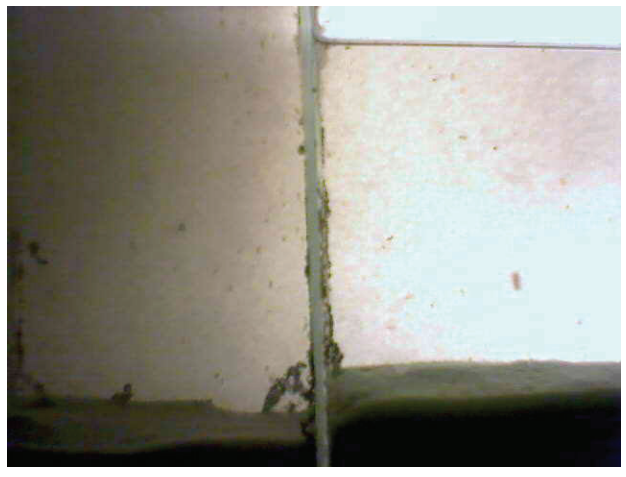

Fig. 6 First taken picture

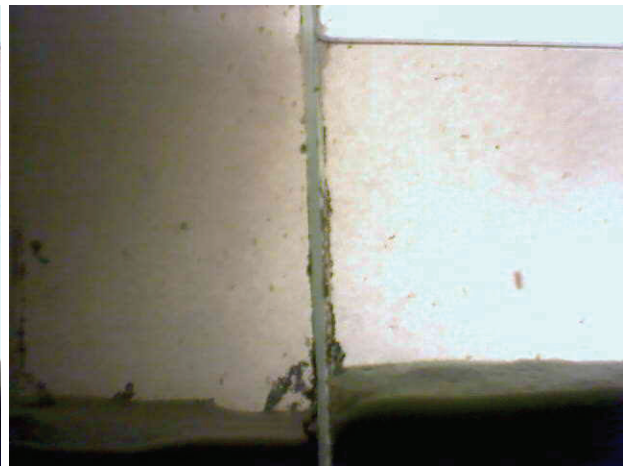

Fig. 7 Next taken picture

The Daphnia coordinates and magnitude (in pixels) are recording in SQL data base. The next picture is taken after some delay, what is in this case given in Fig. 7.

The position and magnitude are recorded in the same way as from previous picture. The output file with recorded data before and after move, are given in Fig.8. 


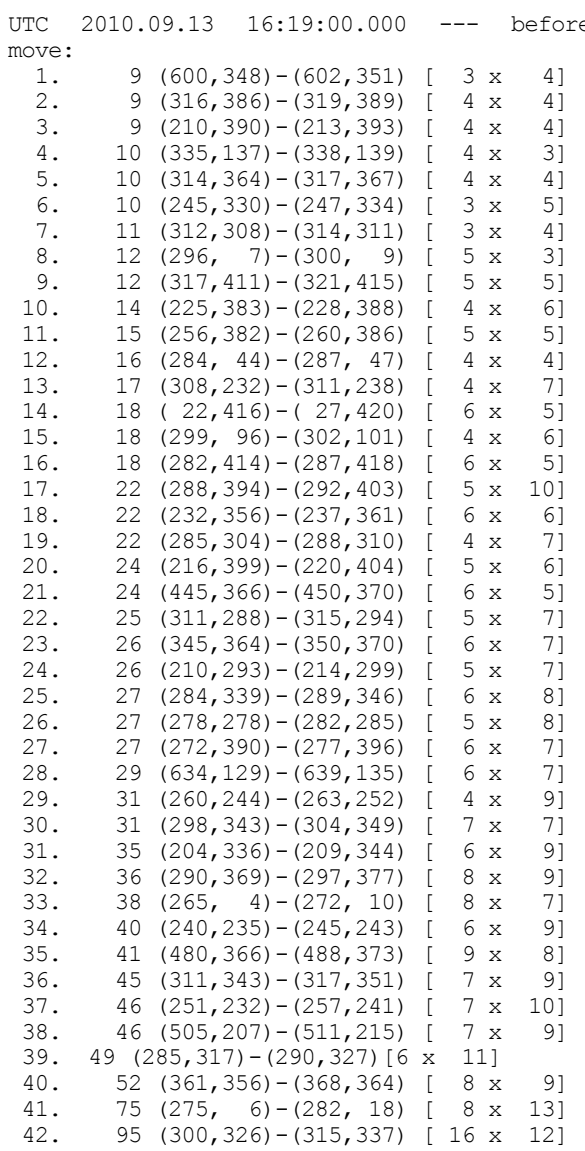

\begin{tabular}{|c|c|c|c|c|c|}
\hline 1. & 9 & $(312,327)-(316,329)$ & & $x$ & 3] \\
\hline 2 . & 9 & $(300,257)-(303,259)$ & 4 & $x$ & 3] \\
\hline 3 . & 9 & $(255,245)-(258,248)$ & 4 & $x$ & 4] \\
\hline 4 . & 10 & $(296,226)-(298,229)$ & & $3 x$ & 4] \\
\hline 5 . & 11 & $(374,378)-(378,380)$ & & $x$ & 3] \\
\hline 6 . & 11 & $(381,56)-(383,60)$ & 3 & $x$ & 5] \\
\hline 7 . & 11 & $(276,417)-(279,420)$ & 4 & $x$ & 4] \\
\hline 8. & 11 & $(303,83)-(305,87)$ & 3 & $\mathrm{x}$ & 5] \\
\hline 9. & 12 & $(288,44)-(292,48)$ & & $x$ & נ \\
\hline 10. & 12 & $(259,234)-(261,238)$ & & $x$ & 5] \\
\hline 11. & 12 & $(226,316)-(229,320)$ & 4 & $x$ & \\
\hline 12 . & 14 & $(309,223)-(313,227)$ & 5 & $5 x$ & 5] \\
\hline 13. & 14 & $(214,411)-(217,415)$ & & $4 x$ & 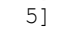 \\
\hline 14. & 16 & $(283,381)-(285,387)$ & 3 & $3 x$ & 7] \\
\hline 15. & 17 & $(306,155)-(311,158)$ & 6 & $6 x$ & 4] \\
\hline 16. & 18 & $(234,392)-(238,396)$ & 5 & $5 x$ & 1 \\
\hline 17. & 18 & $(289,401)-(293,405)$ & & $5 x$ & \\
\hline 18. & 19 & $(205,282)-(208,288)$ & & $4 \times$ & 7] \\
\hline 19. & 20 & $(299,44)-(302,49)$ & 4 & $4 \times$ & 6] \\
\hline 20. & 20 & $(310,281)-(314,287)$ & & $5 x$ & \\
\hline 21. & 21 & $(294,291)-(300,296)$ & & $7 x$ & 6] \\
\hline 22 . & 22 & $(472,369)-(477,374)$ & & $6 x$ & 6] \\
\hline 23. & 23 & $(298,20)-(302,26)$ & 5 & $5 x$ & \\
\hline 24 . & 24 & $(340,380)-(346,385)$ & & $7 \times$ & 6] \\
\hline 25 . & 24 & $(286,344)-(289,351)$ & & $4 x$ & 8] \\
\hline 26. & 25 & $(288, \quad 0)-(296, \quad 3)$ & 9 & $9 x$ & 4] \\
\hline 27. & 25 & $(610,132)-(615,138)$ & & $5 \times$ & 7 \\
\hline 28. & 26 & $(262,416)-(266,422)$ & & $5 x$ & 7] \\
\hline 29. & 26 & $(215,325)-(220,331)$ & & $6 x$ & $1]$ \\
\hline 30 . & 29 & $(273,395)-(279,401)$ & & $7 \mathrm{x}$ & 7] \\
\hline 31 . & 30 & $(246,362)-(250,369)$ & & $5 x$ & 8] \\
\hline 32 . & 31 & $(308,410)-(313,420)$ & 6 & $6 x$ & 11] \\
\hline 33. & 34 & $(285,27)-(290,34)$ & 6 & $6 x$ & 8] \\
\hline 34 & 35 & $(300,365)-(308,370)$ & & $9 x$ & 6] \\
\hline 35 & 36 & $(305,164)-(310,173)$ & 6 & $6 x$ & 10] \\
\hline 36. & 37 & $(273,284)-(277,292)$ & & $5 \mathrm{x}$ & 9] \\
\hline 37 . & 37 & $(237,218)-(242,226)$ & 6 & $6 x$ & 9] \\
\hline 38 & 38 & $(512,206)-(517,215)$ & & $6 x$ & 10] \\
\hline 39. & 38 & $(389,364)-(394,371)$ & 6 & $6 x$ & 8] \\
\hline 40 . & 50 & $(349,366)-(356,372)$ & & $8 \mathrm{x}$ & 7] \\
\hline 41 & 51 & $(279,312)-(284,322)$ & & $6 x$ & $11]$ \\
\hline 42 & 52 & $(257,204)-(262,214)$ & 6 & $6 x$ & $11]$ \\
\hline 43 & 53 & $(303,320)-(311,329)$ & 9 & $9 x$ & 10] \\
\hline 44 & 73 & $(307,334)-(317,347)$ & 11 & $1 \mathrm{x}$ & 14] \\
\hline 4 & 86 & $(261,382)-(273,394)$ & 13 & $3 x$ & 13 \\
\hline 46 & 86 & $(272,403)-(282,415)$ & 11 & $1 \mathrm{x}$ & 13 \\
\hline & 126 & $(281,8)-(299,21)$ & & & 14 \\
\hline
\end{tabular}

Fig. 8 Data recording before and after Daphniae move

Comparison of successive photos given in Figs. 6 and 7 gives resulting photo with Daphnias before (blue) and after move (red) gives picture superimpose, what it presented in Fig. 9.

The same software implemented on the picture of first author taken by web camera gives picture presented in Fig. 10.

In the middle is picture in real time, on the right side upper photo is picture as recorded, on the left side upper, as recorded after delay (600 ms or $1 \mathrm{~s})$, in down corners right and left are black and white gray pho-

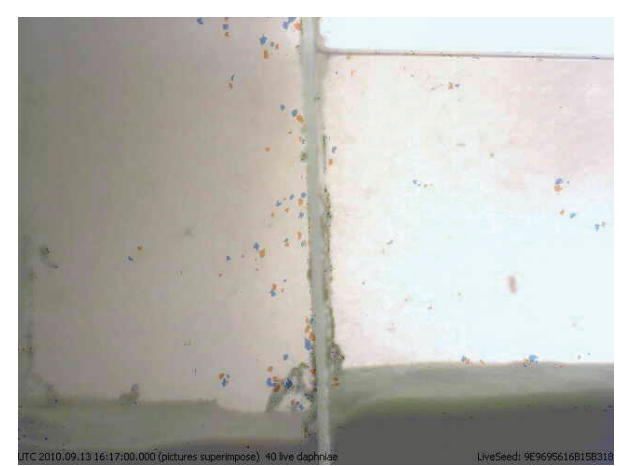

Fig. 9. Superimposed picture 
tos (i.e. after some transformations), and middle down is pictures difference. That algorithm enables immediately counting of Daphniae. In the left down corner of picture is given time and number of Daphniae. In the right down corner of picture is given random number generated by position of Daphniae. The resulting graphic, with numbers of Daphnia in last 24 hours and trend with standard deviation in last hour is given in Fig. 11.

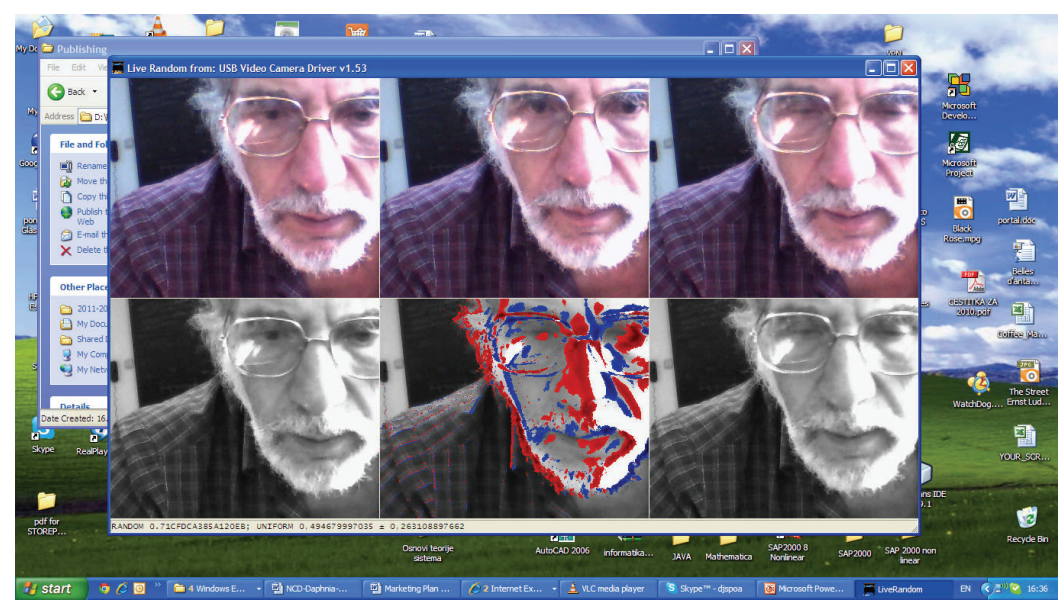

Fig. 10 Example of processing of picture by same software

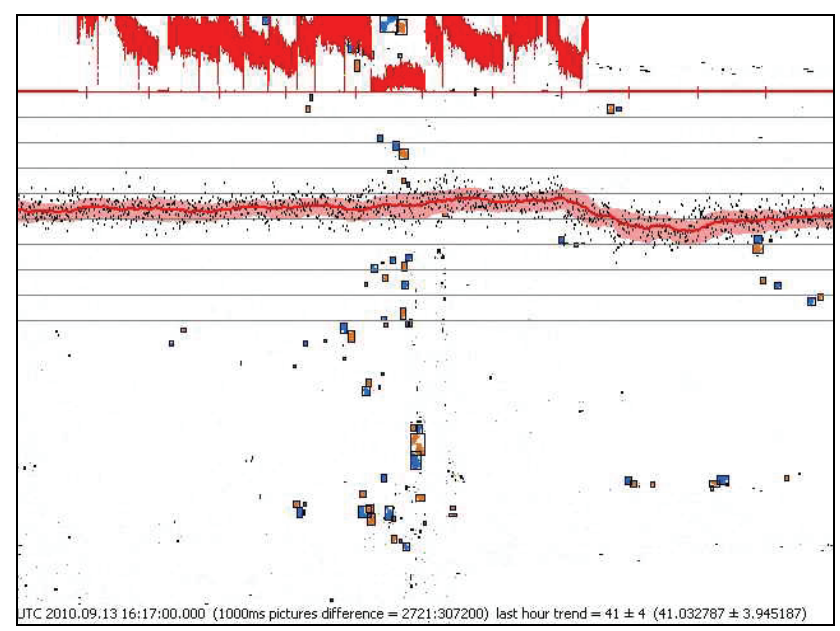

Fig. 11 Round-o-clock number of Daphniae

The data recording round-a-clock for all period the laboratory is working (more than one year) are available on server. SQL data base with cloud technology will enable accessibility to the data globally. The graphic presentation of number of Daphniae in bioassay for longer period of time (in this case, one year), with trends which enable stronger analysis of different influence factors, is given in Fig. 12. 


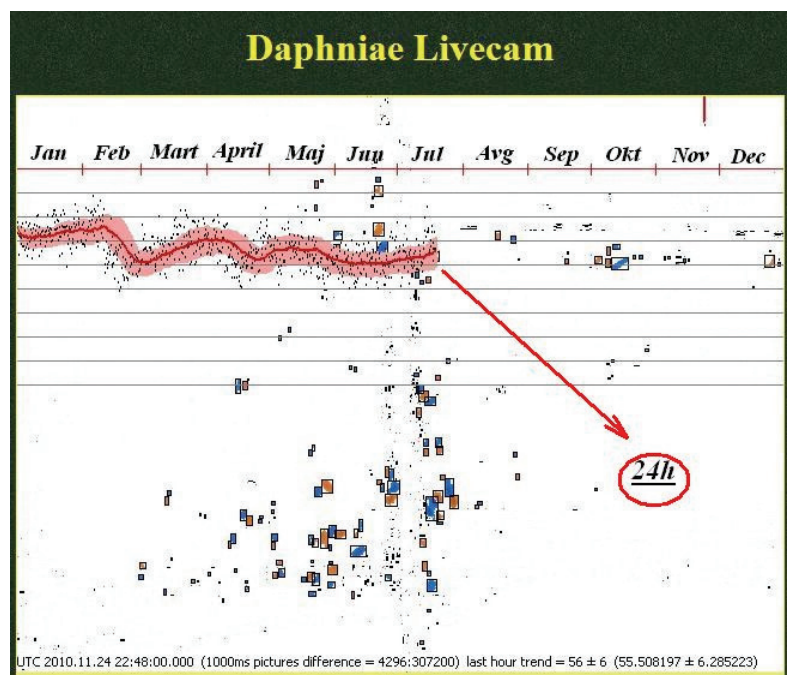

Fig. 12 Long period counting results

\section{BIO-RANDOM NUMBER GENERATOR}

It is often to use linear congruent method that for one random number computes next number as $x_{i+1}=\left(x_{i} a+c\right) \bmod m$. Because it always holds $0 \leq x<m$, then $0 \leq x / m<1$, so that random number is in interval $(0,1)$. The value $x_{0}$ is called seed of random number. Random number generator of hypothetical processor MMIX, which works with 64 bits, has a constants $a=6364136223846793005, c=1442695040888963407$, and $m=2^{64}$, what is given in the following code.

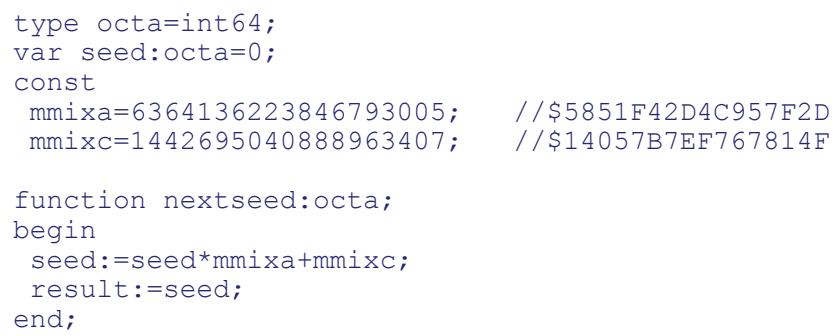

In a similar way it is possible to calculate previous random number $x_{i}=\left(x_{i+1} b+d\right) \bmod m$. Herewith we $\left(\left(x_{i} a+c\right) b+d\right) \bmod m=\left(x_{i} a b+c b+d\right) \bmod m$ have. In order to hold for every $x$, it must be $a b=1 \bmod m$ and $c b=-d \bmod m$. Of course, it holds $x_{i}=\left(\left(x_{i} b+d\right) a+c\right) \bmod m$, wherefrom follows $d a=-c \bmod m$. Next procedure will compute the corresponding values for $a$ and $c, b=-4568919932995229531$ and $d=-7379792620528906219$. 


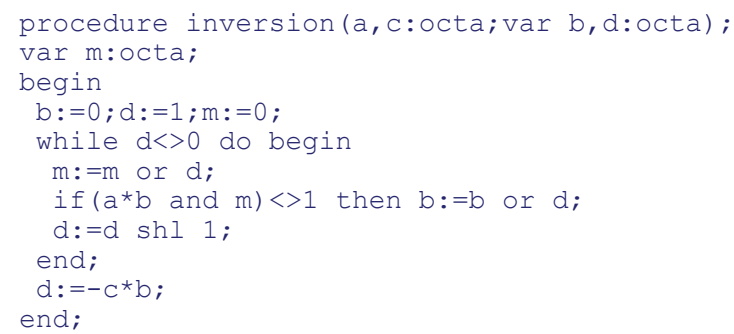

This procedure will compute the previous value of seed:

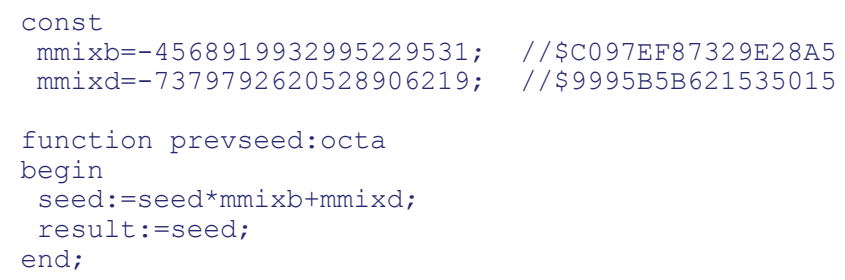

Regardless of using functions nextseed or prevseed, it is the same generator. The same series of numbers will be generated, but direction depends on function choice. For this purpose, the direction will be defined by logical variable direction.

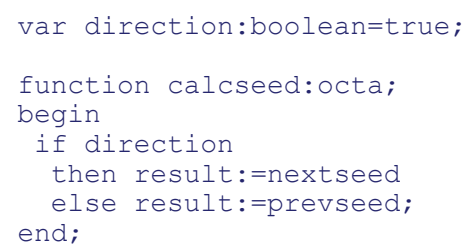

The whole code of random number generator using as a seed Daphnia movements is given in file Nasumica.txt (Available on the above given site, i.e. www.dundjer.co.rs/Daphniae ).

\section{CONCLUSION}

The most important advantage of BIOTOKSINOMER is its prevention function, i.e. preventing the negative consequences of delay of results of standard methods for water quality examination. The standard methods usually give late results because taking water samples in discontinuity, in periods of time. Water sampling for BIOTOKSINOMER is continuous and testing proceeds 24 hours a day. Besides, standard methods demand expensive equipment and reagents, high qualified staff, and they are time consuming. Until results of standard analyses reach the responsible persons, water is already consumed (humans, fish, biosphere) and toxins are spreading through organisms. BIOTOKSINOMER solves this problem in quick, cheap, and ecologically efficient way. 


\section{REFERENCES}

1. Knuth, D.E., The Art of Computer Programming, Addison-Wesley, 1969, vol. 2, pp. 1-160.

2. Djordjević, Dj., Ignjatović, L., Nešić, S.: "Biotoksinomer" - A Bio-Device for Water Quality Control, International Conference "Innovation as a Function of Engineering Development", Faculty of Civil Engineering and Architecture, Niš, November 25-26, 2011, Proceedings, pp. 91-96.

3. Udruženje za tehnologiju vode i sanitarno inženjerstvo, Direktive Evropske Unije o vodama, Beograd, 2005. (in Serbian).

4. G. Persoone, R. Baudo, M. Cotman, C. Blaise, K. Cl. Thompson, M. Moreira-Santos, B. Vollat, A. Törökne, T. Han, "Review on the acute Daphnia magna toxicity test - Evaluation of the sensitivity and the precision of assays performed with organisms from laboratory cultures or hatched from dormant eggs," Knowledge and Management of Aquatic Ecosystems, 393, 01, 2009.

5. ISO 6341: Water Quality - Determination of the Inhibition of the Mobility of Daphnia magna Straus (Cladocera, Crustacea), 15 March 1982.

\section{PRIMENA BIOLOŠKOG SENZORA BAZIRANOG NA DAFNIJAMA KAO GENERATORA SLUČAJNIH BROJEVA}

\section{Đorđe Đorđević, Srbislav Nešić}

Jedan od najčešće korišćenih indikatora prisustva hemijskih $i$ toksičnih materia u vodi je standardni test pomoću vodenih račića Dafnija (Daphnia Pullex ili Daphnia Magna). Standardne metode su razvijene $i$ neprekidno se usavršavaju od strane nacionalnih $i$ medjunarodnih organizacija koje se bave procedurama testova toksičnosti, posebno njihovom primenom $u$ regulatornim (zakonskim) okvirima. Kao i za sve testove toksičnosti, organizmi koji se koriste za Dafnija test moraju se obezbediti iz laboratorijski odgajenih kultura, hranjenih živom hranom (mikro-alge).Tehnički i biološki problemi koji proizilaze iz godišnjeg ciklusa gajenja Dafnija $i$ troškovi gajenja/održavanja živih organizama ograničavaju primenu ovog testa na ograničen broj viskoko specijalizovanih laboratorija. To usko grlo u testiranju toksičnosti pospešilo je istraživanja ka konceptu "mikrobiotestova" ili "small-scale" testova toksičnosti. Ovaj rad se bavi merenjem promena ponašanja Dafnija koristeći uredjaj BIOTOKSINOMER, nagradjen od strane Ministarstva za nauku i tehnološki razvoj Republike Srbije Diplomom za najbolju inovativnu ideju u 2010. godini u kategoriji Medicina, zdravlje i ekologija. Glavna tema rada je digitalizacija rezultata bio-monitoringa i generisanje slučajnih brojeva na osnovu kretanja Dafnija. On-line praćenje ponašanja Dafnija je omogućeno na sajtu www.dundjer.co.rs/Daphniae i open-source softverska podrška je raspoloživa na istom sajtu.

Ključne reči: bio-senzori,merenje kvaliteta vode, generator slučajnih brojeva 